\title{
PENERAPAN METODE INKUIRI UNTUK MENINGKATKAN HASIL BELAJAR MATEMATIKA SISWA KELAS V SD NEGERI 023905 KEBUN LADA
}

\section{OLEH: \\ PINDO HUTAURUK (DOSEN PGSD FKIP UNIVERSITAS QUALITY)}

\begin{abstract}
The purpose of this study was to improve the mathematics learning outcomes of class V students of SD Negeri 023905 Kebun Lada by applying the inquiry method. This research is Classroom Action Research (CAR) which consists of 2 cycles and each cycle consists of: 1) planning, 2) implementation, 3) observation, and 4) reflection. Data collection techniques are carried out by observing activities and learning outcomes tests. The results showed an increase in learning outcomes of Class V students of SD Negeri 023905 Kebun Lada. It can be seen from the results of the implementation of teacher activity learning that it increased from $70 \%$ with a fairly good category in the first cycle to $85 \%$ with a good category in the second cycle, while from the observation the implementation of student learning activities increased from $65 \%$ to the poor category in the first cycle $85 \%$ in the good category in cycle II. Furthermore, classical learning completeness of students has increased from $63.64 \%$ in the first cycle to $90.91 \%$ in the second cycle.
\end{abstract}

Keywords: Inquiry Method, Learning Outcomes.

\section{PENDAHULUAN}

\section{Latar Belakang Masalah}

Matematika merupakan mata pelajaran yang wajib diajarkan disetiap jenjang pendidikan mulai dari SD, SMP, SMA bahkan sampai ke perguruan tinggi. Salah satu alasan mengapa matematika perlu diajarkan disetiap jenjang pendidikan karena matematika dapat digunakan untuk memecahkan masalah dalam kehidupan sehari-hari.. Hal ini diperkuat oleh Cockroft (dalam Abdurrahman, 2003:263) mengemukakan bahwa:

"Matematika perlu diajarkan kepada siswa karena (1) selalu digunakan dalam segala segi kehidupan; (2) semua bidang studi memerlukan matematika yang sesuai; (3) merupakan sarana komunikasi yang kuat, 
singkat, dan jelas; (4) dapat digunakan untuk menyajikan informasi dalam berbagai cara; (5) meningkatkan kemampuan berpikir logis, ketelitian, dan kesadaran keruangan; dan (6) memberikan kepuasan terhadap usaha memecahkan masalah yang menantang".

Melihat begitu pentingnya pembelajaran matematika diberikan diberbagai jenjang pendidikan formal, diharapkan pembelajaran ini dapat dikuasai oleh siswa dengan baik. Namun, kenyataanya menunjukkan bahwa matematika merupakan salah satu pembelajaran`yang sulit untuk dipelajari. Mulyono Abdurrahman (2003:252) mengemukakan bahwa: "Dari berbagai bidang studi yang diajarkan di sekolah, matematika merupakan bidang studi yang dianggap paling sulit oleh para mahasiswa, baik yang tidak berkesulitan belajar dan lebih-lebih bagi para siswa berkesulitan belajar".

Berdasarkan hasil pengamatan penulis bahwa hasil belajar matematika siswa Kelas V SD Negeri 023905 Kebun Lada Tahun Ajaran 2018/2019 masih tergolong rendah. Dimana dalam ulangan harian diperoleh nilai $\leq 65$ sebanyak 7 siswa $(31,82 \%)$ siswa tidak tuntas belajar dan siswa yang memperoleh nilai $\geq 65$ sebanyak 15 siswa (68.18\%) siswa tuntas belajar. Hal ini mununjukkan bahwa hasil belajar matematika siswa rendah, sebab persentase ketuntasan belajar klasikal harus mencapai $\geq 85 \%$ siswa yang telah tuntas belajar.

Penyebab rendahnya hasil belajar matematika siswa salah satunya yaitu karena dalam pelaksanaan pembelajaran matematika, metode pembelajaran yang digunakan kurang tepat. Untuk itu guru harus mampu berusaha menciptakan suasana belajar yang kondusif sehingga dapat membangkitkan semangat siswa untuk lebih giat dan aktif dalam kegiatan proses pembelajaran.

Permasalahan di atas dapat diatasi apabila dapat merancang pembelajaran dengan motode pembelajaran yang tepat. Salah satu metode yang dapat digunakan adalah dengan penerapkan metode inkuiri yaitu metode penemuan yang berpusat pada siswa. Metode inkuiri adalah salah satu metode yang dapat membuat siswa aktif dalam kegiatan belajar mengajar untuk menyelidiki kebenaran suatu informasi tentang materi pelajaran sampai siswa menemukan sendiri dan memecahkan masalah dengan proses mentalnya.

Metode Inkuiri juga dapat dimanfaatkan untuk mengatasi pembelajaran 
yang bersifat verbalisme atau dengan kata-kata sehingga mengajak siswa lebih aktif dalam mengikuti pembelajaran. Metode Inkuiri tersebut dapat membantu siswa untuk memahami materi pelajaran yang diberikan karena tidak hanya sekedar hapalan. W.Gulo (2002:84) menyatakan bahwa: "Inkuiri adalah suatu rangkaian kegiatan belajar yang melibatkan secara maksimal seluruh kemampuan siswa untuk mencari dan menyelidiki secara sistematis, kritis, logis, analitis, sehingga mereka dapat merumuskan penemuannya sendiri dengan penuh percaya diri”. Berdasarkan uraian di atas, penulis akan mencoba melakukan penelitian dengan menggunakan metode inkuiri.

\section{METODOLOGI PENELITIAN}

Penelitian ini dilaksanakan di sekolah SD Negeri 023905 Kebun Lada, Semester ganjil tahun pelajaran 2018/2019. Subjek penelitian ini adalah siswa Kelas V SD Negeri 023905 Kebun Lada Kecamatan Binjai Utara - Kota Binjai yang berjumlah 22 siswa. Yang menjadi objek penelitian ini adalah penerapan metode inkuiri dalam mata pelajaran matematika pokok bahasan geometri di kelas V SD Negeri 023905 Kebun Lada. Penelitian ini merupakan Penelitian Tindakan Kelas (PTK), Arikunto (2014:16) memiliki empat tahap yaitu; 1) perencanaan, 2) pelaksanaan, 3) pengamatan, dan 4) refleksi. Untuk pengumpulan data dalam penelitian ini, alat pengumpulan data yang digunakan adalah Observasi dan tes.

Analisis data dilakukan melalui tiga tahap yaitu: reduksi data, paparan data, dan peyimpulan data. Untuk mengetahui tingkat kemampuan siswa yang diperoleh dari hasil belajar secara individu dan klasikal menggunakan rumus Usman (2004:64) yang mengemukakan tentang ketuntasan belajar siswa secara individual dan klasikal yaitu:

1. Seorang siswa dikatakan telah tuntas belajar jika siswa tersebut mencapai skor paling sedikitnya $65 \%$ dari total skor.

2. Suatu kelas dikatakan telah tuntas belajar jika dalam kelas tersebut telah terdapat paling sedikitnya $85 \%$ dari jumlah siswa seluruhnya telah mencapai skor $65 \%$. 
Untuk mengetahui persentase hasil belajar siswa secara individu, dapat digunakan rumus sebagai berikut :

$\mathrm{PHB}=\frac{A}{B} \times 100 \%$

dimana $:$ PHB = Persentase Hasil Belajar Siswa

$$
\begin{aligned}
& \mathrm{A}=\text { Skor yang diperoleh siswa } \\
& \mathrm{B}=\text { Skor maksimal }
\end{aligned}
$$

Selanjutnya persentase siswa yang telah tuntas belajar secara klasikal dapat dirumuskan sebagai berikut:

$$
D=\frac{X}{N} \times 100 \%
$$

dimana :

$\mathrm{D}=$ Persentase ketuntasan belajar klasikal

$\mathrm{X}=$ Jumlah siswa yang telah tuntas belajar

$\mathrm{N}=$ Jumlah seluruh siswa

Kriteria ketuntasan belajar secara klasikal akan diperoleh jika di dalam kelas tersebut terdapat $\geq 85 \%$ siswa yang telah mencapai nilai $\geq 65 \%$

Untuk mengetahui nilai rata-rata siswa, maka rumus yang digunakan adalah rumus (Zainal Aqib, 2010:40).

Nilai rata-rata $=\frac{\text { Jumlah semua nilai siswa }}{\text { Jumlah siswa }}$

Hasil observasi aktivitas guru dan siswa dihitung dengan menggunakan rumus:

Nilai $=\frac{\text { Jumlah skor yang didapat }}{\text { jumlah skor maksimal }} \times 100$ (Jainab, 2015:108)

Peneliti menggunakan kriteria ketuntasan individu $\geq 65 \%$ dan ketuntasan klasikal $\geq 85 \%$ sedangkan untuk kriteria hasil observasi pelaksanaan pembelajaran aktivitas guru dan siswa tercapai bila nilainya $\geq 80$ didasarkan pada Standar Ketuntasan Belajar Mengajar yang ditetapkan oleh SD Negeri 023905 Kebun Lada. 


\section{HASIL DAN PEMBAHASAN}

\section{Hasil Penelitian Siklus I}

Hasil pelaksanaan pembelajaran aktivitas guru dan hasil observasi pelaksanaan pembelajaran siswa pada siklus I adalah sebagai berikut:

a. Hasil pelaksanaan pembelajaran aktivitas guru pada siklus I diperoleh sebesar $70 \%$ dengan kriteria cukup.

b. Hasil observasi pelaksanaan pembelajaran aktivitas siswa pada siklus I diperoleh sebesar 65\% dengan kriteria kurang.

\section{Ketuntasan Hasil Belajar Siswa Siklus I}

\begin{tabular}{|l|c|c|}
\hline \multicolumn{1}{|c|}{ Keterangan } & Jumlah Siswa & Persentase \\
\hline Siswa yang tuntas belajar & 14 & $63,64 \%$ \\
\hline Siswa yang tidak tuntas belajar & 8 & $36,36 \%$ \\
\hline Jumlah siswa & 22 & $100 \%$ \\
\hline Nilai Rata-rata & \multicolumn{2}{|c|}{70} \\
\hline
\end{tabular}

\section{Refleksi Siklus I}

Hasil observasi pelaksanaan pembelajaran aktivitas guru yang dilakukan oleh observer (guru kelas) pada siklus I bahwa dalam penerapan model inkuiri pada mata pelajaran matematika pokok bahasan Geometri Kelas V SD Negeri 023905 Kebun Lada Tahun Ajaran 2018/2019 belum berjalan dengan baik. Terlihat beberapa kekurangan yang diperoleh yaitu penggunaan alokasi waktu belum sesuai dengan rencana pelaksanaan pembelajaran, kurang memotivasi siswa untuk bertanya. Sedangkan hasil observasi siswa juga ada beberapa kekurangan yang diperoleh yaitu: kurang tepat waktu dalam memasuki kelas, masih ada siswa kurang mampu dalam merumuskan masalah, masih ada siswa kurang aktif bertanya, masih ada beberapa siswa kurang mampu merumuskan kesimpulan.

Solusi untuk memperbaiki kendala di atas guru harus lebih rileks dalam menyampaikan pembelajaran, guru lebih memperhatikan pembelajaran sesuai dengan urutan kegiatan pembelajaran, penggunaan alokasi waktu harus sesuai dengan rencana pelaksanaan pembelajaran, guru harus memotivasi siswa untuk bertanya. 
Ketika guru sudah memperbaiki kelemahan-kelemahan hal diatas maka diharapkan terciptanya perbaikan pada pelaksanaan pembelajaran akan membawa dampak pada peningkatan hasil belajar siswa pada siklus ke II.

\section{Hasil Penelitian Siklus II}

Hasil pelaksanaan pembelajaran aktivitas guru dan hasil observasi pelaksanaan pembelajaran siswa pada siklus I adalah sebagai berikut:

a. Hasil pelaksanaan pembelajaran aktivitas guru pada siklus I diperoleh sebesar $85 \%$ dengan kriteria baik.

b. Hasil observasi pelaksanaan pembelajaran aktivitas siswa pada siklus I diperoleh sebesar $85 \%$ dengan kriteria baik.

\section{Ketuntasan Hasil Belajar Siswa Siklus I}

\begin{tabular}{|l|c|c|}
\hline \multicolumn{1}{|c|}{ Keterangan } & Jumlah Siswa & Persentase \\
\hline Siswa yang tuntas belajar & 20 & $90,91 \%$ \\
\hline Siswa yang tidak tuntas belajar & 2 & $9,09 \%$ \\
\hline Jumlah siswa & 22 & $100 \%$ \\
\hline Nilai Rata-rata & \multicolumn{2}{|c|}{85} \\
\hline
\end{tabular}

\section{Pembahasan}

Metode inkuiri merupakan metode pembelajaran yang melibatkan seluruh kemampuan siswa dalam menyelidiki penemuannya secara sistematis, kritis, logis dan analitis. Pengetahuan yang diperoleh siswa diharapkan bukan hasil mengingat seperangkat fakta-fakta, tetapi hasil menemukan sendiri. Selanjutnya, Piaget (dalam Mulyasa, 2003:108) menyatakan bahwa; "Metode inkuiri merupakan metode yang mempersiapkan peserta didik pada situasi untuk melakukan eksperimen sendiri secara luas agar melihat apa yang terjadi, ingin melakukan sesuatu, mengajukan pertanyaan-pertanyaan, dan mencari jawaban sendiri, serta menghubungkan penemuan yang satu dengan yang lain, membandingkan apa yang ditemukannya dengan yang ditemukan peserta didik lain”.

Dalam penelitian sebelumnya yang telah dilakukan Israwani (2015) dalam penelitiannya yang berjudul penggunaan model pembelajaran inkuiri pada materi operasi hitung bilangan di kelas I SD Negeri 53 Banda Aceh menyimpulkan bahwa aktivitas guru mengalami peningkatan dari siklus I sampai ke siklus II, aktivitas siswa juga mengalami peningkatan dari siklus I sampai ke siklus II, dan 
hasil belajar siswa juga mengalami peningkatan yang signifikan dari siklus ke siklus. Selanjtnya Jufri, Sarjan N. Husainn dan Ritman Ishak Paudi dalam penelitiannya yang berjudul penerapan metode inkuiri dalam meningkatkan hasil belajar siswa SD Inpres 2 Ambesia menyimpulkan bahwa penerapan metode inquiri dapat meningkatkan hasil belajar siswa kelas IV SD Inpres 2 Ambesia.

Berdasarkan teori di atas dan hasil penelitian terdahulu maka peneliti tertarik untuk melakukan penelitian tindakan kelas dengan penerapan motede pembelajaran inkuiri. Judul penelitian yang peneliti lakukan adalah Penerapan Metode Inkuiri untuk Meningkatkan Hasil Belajar Matematika Siswa Kelas V SD Negeri 023905 Kebun Lada.

Berdasarkan penelitian yang dilakukan oleh peneliti maka dapat dilihat bahwa pada siklus I memperoleh nilai 70\%, sedangkan pada siklus II memperoleh nilai $85 \%$. Dari pernyataan tersebut dapat disimpulkan pelaksanaan pembelajaran aktivitas guru pada siklus II meningkat dengan kategori baik. Selanjutnya Peningkatan aktivitas siswa, Pada siklus I memperoleh nilai 65\%, sedangkan pada siklus II memperoleh nilai $85 \%$. Dari pernyataan tersebut, dapat disimpulkan bahwa hasil observasi pelaksanaan pembelajaran aktivitas siswa pada Siklus II meningkat dengan kategori baik.

Sedangkan untuk hasil ketuntasan belajar siswa secara klasikal adalah sebagai berikut:

a. Ketuntasan hasil belajar siswa secara klasikal pada Siklus I yaitu siswa yang mencapai tuntas atau mendapat nilai $\geq 65$ hanya sebanyak $14(63,64 \%)$ dari 22 siswa. Hal ini berarti secara klasikal siswa yang tuntas hanya 63,64\%, sedangkan untuk memenuhi ketuntasan yang efektif secara klasikal harus mencapai $85 \%$, sehingga dapat dikatakan bahwa pada siklus I hasil belajar siswa dikatakan belum tuntas secara klasikal.

b. Ketuntasan hasil belajar siswa secara klasikal pada Siklus II yaitu 20 siswa $(90,91 \%)$ dari 22 siswa. Berarti secara klasikal hasil belajar siswa telah mencapai 90,91\%, sehingga dapat disimpulkan bahwa pada siklus II ketuntasan belajar siswa secara klasikal dengan Penerapan Metode Inkuiri 
untuk Siswa Kelas V SD Negeri 023905 Kebun Lada Tahun Ajaran 2017/2018 mengalami peningkatan dibandingkan siklus I.

Berdasarkan hasil pengamatan pembelajaran pada siklus II terlihat perubahan hasil belajar siswa dari 22 siswa maka diperoleh siswa yang tuntas belajar sebanyak 20 siswa $(90,91 \%)$. Dengan peningkatan hasil belajar siswa dari siklus I ke siklus II maka tidak perlu melanjutkan pembelajaran pada siklus berikutnya.

\section{PENUTUP}

\section{Simpulan}

Berdasarkan hasil penelitian yang dilaksanakan pada kelas V SD Negeri 023905 Kebun Lada Tahun Ajaran 2018/2019 dapat disimpulkan sebagai berikut:

1. Pelaksanaan pembelajaran melalui penerapan metode inkuiri dapat berjalan dengan baik. Terlihat dari hasil pelaksanaan pembelajaran aktivitas guru yang berkategori cukup menjadi baik dan hasil observasi pelaksanaan pembelajaran aktivitas siswa dari kategori kurang menjadi baik.

2. Pelaksanaan pembelajaran melalui penerapan motode inkuiri dapat meningkatkan hasil belajar matematika siswa Kelas V SD Negeri 023905 Kebun Lada.

\section{Saran}

1. Bagi guru, pembelajaran matematika dengan penerapan motode inkuiri dapat diperluas penggunaanya tidak hanya pada pokok bahasan geometri tetapi juga pada pokok bahasan matematika lainnya. Penerapan motode inkuiri haruslah melalui persiapan yang matang agar proses pembelajaran dapat berjalan dengan lancar sebab metode pembelajaran ini memerlukan waktu yang banyak.

2. Bagi sekolah, hendaknya memberikan perhatian dan dorongan terhadap guru disekolah untuk menciptakan pembelajaran yang inovatif salah satunya yaitu dengan penerapkan motode inkuiri serta memfasilitasi sarana dan prasarana dalam rangka meningkatkan hasil belajar siswa.

3. Bagi peneliti lanjut, yang akan mengadakan penelitian dengan jenis yang sama dengan penelitian ini dapat dijadikan sebagai bahan perbandingan dan bahan masukan. 


\section{DAFTAR PUSTAKA}

Abdurrahman, M. 2003. Pendidikan Bagi Anak Berkesulitan Belajar. Jakarta: Rineka Cipta

Aqib, Z. 2010. Penelitian Tindakan Kelas. Bandung: Yrama Widya

Arikunto, S. 2006. Penelitian Tindakan Kelas. Jakarta. Bumi Aksara

Djamarah, SB. \& Zain, Aswan. 2002. Strategi Belajar Mengajar. Jakarta: Rineka Cipta.

Gulo, W. 2002. Strategi Belajar Mengajar. Jakarta: Gramedia Widiasarana Indonesia

Israwani. 2015. Penggunaan Model Pembelajaran Inkuiri Pada Materi Operasi Hitung Bilangan Di Kelas I Sd Negeri 53 Banda Aceh. file:///C:/Users/axioo/Downloads/5717-11652-1-SM.pdf. Jurnal Peluang, Volume 3, Nomor 2, ISSN: 2302-5158, hal 55 - 64 (diakses pada tanggal 20 Januari 2019)

Jainab. 2015. Upaya Peningkatan Hasil Belajar PKn dengan Menggunakan Model Pembelajaran Kooperatif Jigsaw pada Pokok Bahasan Otonomi Daerah Kelas IX di SMP Negeri 3 Kabanjahe T.P 2012/2013. Jurnal Saintech. Vol.07- No.01: 104 - 116

Jufri, dkk. 2014. Penerapan Metode Inkuiri Dalam Meningkatkan Hasil Belajar Siswa SD Inpres 2 Ambesia. https://media.neliti.com/media/publications/108873-ID-penerapan-metodeinkuiri-dalam-meningkat.pdf. Jurnal Kreaif Tadulako Online Vol. 4 No. 6, ISSN 2354-614X, hal 200 - 211 (diakses pada tanggal 20 Januari 2019)

Mulyasa,E. 2003. Menjadi Guru Professional. Bandung: Remaja Rosdakarya

Nurani, Yuliani. 2003. Strategi Pembelajaran. Universitas Jakarta.

Sanjaya, Wina. 2011. Strategi Pembelajaran Berorientasi Standar Proses Pendidikan. Jakarta: Kencana

Syah, Muhibbin .2004. Psikologi Pendidikan Dengan Pendekatan Baru. Bandung: PT Remaja Rosdakarya

Usman, Uzer. 2004. Menjadi Guru Profesional. Bandung: Remaja Rosdakarya 